\title{
Differences in Reading Strategies Employed by Students Constructing Graphic Organizers and Students Producing Summaries in EFL Reading
}

\author{
Akio Suzuki \\ Josai University
}

The big difference between summaries and graphic organizers (GOs) as adjunct aids for EFL reading is that GOs can reduce the cognitive burden on readers because of their two-dimensional spatial displays while summaries cannot. In this study, five Japanese high school students were required to construct GOs and another five were required to produce summaries while reading a passage written in English. They were required to report what they were thinking while reading the passage and producing adjunct aids so that their use of reading strategies could be examined. The results gained from think-aloud protocol analysis indicated that the GO group reported more general comprehension strategies than the summary group. The findings are discussed from the perspective that the task of constructing the GOs using visual argument allowed the students to employ more general comprehension strategies.

学習者の英文読解を補助するために、要約を書かせる方法と英文の構成を図式化させる 方法（Graphic Organizer；GO）がある。両者の最も大きな違いはGOの場合、二次元の 空間配置を利用することによって読み手の認知的負荷を軽減できることにある。本研究で は 5 名の被験者に構成図を、5名の被験者に要約を書かせる課題を与え、使用される読解 方略の違いをプロトコル分析によって検討した。分散分析の結果、構成図を書いた群は、 要約を書いた群よりも、テキスト全体の構成に関わる読解方略を多く使用し、言語的な情 報に関わる読解方略を少なくすることが示された。図式化した読者は情報を視覚化するこ とにより、より包括的な読解方略を使ったためであろうという解釈がなされた。

JALT Journal, Vol. 28, No. 2, November, 2006 


\section{Graphic organizers and summaries as adjunct aids in EFL Reading}

With regard to instructional techniques to teach English as a foreign language for teaching reading, there are currently a variety of adjunct aids, such as outlines (see Silberstein, 1994), summaries (see Irwin, 1986), typographical cueing (see Hershberger \& Terry, 1965), phrase reading (see Hatch, 1979), pictures (see Omaggio, 1979), and graphic organizers (see Grabe \& Stoller, 2002). Adjunct aids are assumed to facilitate students' comprehension of a text, either by attaching further reference material to a sentential text or by requiring students to independently produce summaries or graphic organizers.

Among adjunct aids, the writing of summaries has recently become relatively popular as a technique for facilitating students' comprehension in EFL reading classes in Japan. A number of reading texts authorized by the Ministry of Education and Science, such as New Cosmos Reading (Ohura, Tennuma, Ando, Toda, \& Yanagisawa, 2002) and Sunshine Reading (Hashimoto, Ibe, Furukawa, \& Takanashi, 2002) among others include summary production tasks. Considering that a number of reading texts include summary tasks and that many Japanese teachers use this technique for the comprehension of texts, it is safe to say that the writing of summaries is likely to be one generally accepted adjunct display used for EFL reading classes in Japan. Several studies have shown that the writing of summaries enhances both comprehension and memory (Rinehart, Stahl, \& Erickson, 1986; Winograd \& Bridge, 1986).

Like summary production, the use of graphic organizers (GOs, hereafter) as visual adjunct displays is also becoming popular; in fact, foreign language educators have long taken it for granted that visual aids are generally useful for the learning of a foreign language (Omaggio, 1979). GOs are understood to be a type of adjunct display developed so as to facilitate learners' understanding of important interconceptual relations through the use of spatially displayed information (Robinson, 1998). A number of empirical studies have investigated GOs' facilitative effectiveness in text comprehension in a native language (e.g., Levie \& Lentz, 1982; Mayer, 1997; Robinson \& Kiewra, 1995; Robinson, Robinson, \& Katayama, 1999; Sims \& Hegarty, 1997; Waller \& Whalley, 1987; Winn, 1987; Winn, Li, \& Schill, 1991).

There has been a variety of research that has reported positive outcomes concerning GO's facilitative effectiveness in text comprehension when students are asked to construct their own GOs (e.g., Alesandrini, 1981; Alvermann \& Boothby, 1986; Barron, 1980; Dean \& Kulhavy, 1981; 
Geva, 1983; Hawk, 1986; Holley \& Dansereau, 1984; 1981; Novak, 1991; Snowman \& Cunningham, 1975). In one study on student-constructed GOs, Bean, Singer, Sorter, and Frazee (1986) investigated the facilitative effectiveness of three written-product format treatments: (a) GOs-plussummary-training, (b) GOs only, and (c) outlining only, with a group of 10th-grade students using history passages. Although their results revealed no significant differences between the three groups on short-term probes, the performance of the GOs plus summarization training group was significantly better than both the graphic-organizer and outlining groups on a delayed measure. In addition, on a written transfer passage, participants in both the graphic-organizer groups constructed significantly better summary paragraphs.

The act of constructing GOs and that of producing a sentential summary have several features in common (see Bean, et al., 1986), and, in fact, Moore, Chan, and Au (1993) have referred to graphic organizers as diagrammatic summaries (p. 59). Both summaries and GOs are expected to be effective in helping students comprehend texts better, but the crucial difference between the two is that GOs take the form of two-dimensional spatial displays whereas summaries take the form of one-dimensional sentential displays.

With regard to this difference, Larkin and Simon (1987) argued that one-dimensional sentential displays are comprised of sequential propositions such as sentences found in a text, while two-dimensional spatial displays, indexed by location in a plane, explicitly represent information that is only implicit in sentential displays. To be more specific, when information is presented as text, a linear search is required. When the first relevant element concerning a particular concept is found and processed, it must be stored in the memory before the search can continue for the next relevant element. This routine of find and process must continue in this fashion in the working memory of the student until the last element is found and processed. This will inevitably place a great deal of strain on the student's cognitive resources and, as a result, it is likely that a reading error may occur. In the case of spatial displays, however, once a relevant element is found, the next element appears next to or near it. Due to this advantage, the burden upon the working memory of a student is reduced since both elements concerning the concept can be viewed simultaneously and thus efficiently. Larkin and Simon (1987) specifically referred to the efficiency of two-dimensional spatial displays as computational efficacy.

Between reading in a native language (L1) and in a foreign or second language (L2), a large difference can be expected in the cognitive burden. 
In fact, researchers have posited a number of linguistic and processing differences between reading texts in L1 and L2 from a variety of perspectives, including lexical access (e.g., Grabe, 1999), knowledge of grammar (e.g., Urquhart \& Weir, 1998), orthographic depth (e.g., Koda, 1999), and language threshold (e.g., Alderson, 2000). The general consensus is that reading texts in a foreign language puts readers under considerable strain, which can prevent them from gaining a completely effective understanding of the texts. However, it is my impression from the literature that if students construct GOs while reading a text written in English, their cognitive burden might reasonably be lowered, not only in the process but also once they have the GO product to refer to and to display. This can accordingly affect the students' use of reading strategies.

Barnett (1988) summarized previous research on reading strategies and categorized them broadly into two types: one for comprehension at a text level and the other for comprehension at a word or grammar level. Similarly, Block (1986) categorized reading strategies broadly into two types: general comprehension strategies and local linguistic strategies. A general comprehension strategy involves readers' recognizing text structure or integrating information at the text level, while local linguistic strategy deals with the attempt to understand specific linguistic units.

Because the differences in the ways of displaying information-twodimensional spatial displays (GOs) and one-dimensional sentential displays (text summaries) — can influence the cognitive burden placed on EFL readers, the expected proportion of strategy use should vary depending on whether students construct GOs or produce summaries while reading a text written in English, as the type of strategy chosen reveals readers' cognitive resources in comprehension (Langer, 1982).

\section{Purpose and Hypothesis}

The purpose of this study is to examine to what extent, if any, the production of different adjunct display types-graphic organizer (spatial) vs. summary (prose sentence) displays will cause EFL students to rely on different proportions of strategy use (categories according to Block, 1986) when reading a text written in English. My hypothesis is that in the process of constructing GOs, students will inevitably use greater cognitive resources for general reading comprehension strategies, such as recognizing text structure and integrating information, than those who instead produce summaries. This is because GOs possess the advantage of computational efficacy (Larkin \& Simon, 1987), which is a particular 
feature of two-dimensional spatial-display representations, such as maps, charts, graphs, and GOs. Students using such displays can see explicit, graphically-presented relationships, making it easier to formalize connections among concepts while reading. Spatial arrangement allows for data connections to be made more easily in GOs than in prose summaries, in which students must (a) search through many sentences to find one fact, (b) keep that fact in the working memory, (c) search for other facts and, finally, (d) draw inferences between and among the facts. Displaying, rather than describing, the organization or structure of concepts reduces the effort required to comprehend the intended message (Winn, 1990). In this paper I shall try to demonstrate that GOs possess the dual virtue of being (a) user-friendly (as product) and (b) cognitively challenging and therefore rewarding to construct (as process). Students will inevitably use greater cognitive sources for general comprehension reading strategies, such as recognizing text structure or integrating information, than those in the summary group, who are asked to produce summaries, which have, however, no relationship to computational efficacy, and thus need not to be aware of text structure or integrate information.

\section{Method}

\section{Participants and Design}

The participants in this study were initially 15 female third-year senior high school students (ages 17 to 18; all native speakers of Japanese). However, five were ultimately excluded because they failed to complete the assigned tasks of constructing GOs or writing summaries. Thus, the data of 10 participants was used in this study. All were students in my class, a one-year compulsory English course, and all participated in this study voluntarily. As I had previously introduced and used GO techniques, all participants had had the experience of producing GOs.

The participants were randomly divided into two groups. One group was required to produce GOs during or after reading a text in order to enhance comprehension, while the other group was required to write summaries for the same purpose and under the same conditions. In order to ensure the homogeneity of English reading levels between the two groups, an English reading skills test was conducted. English reading levels were determined using the reading portion of a TOEFL sample (Educational Testing Service, 1998). The average score of the ten participants was 20.00 out of 50 . According to the $t$ test, the average TOEFL reading skills of the two groups did not differ significantly, $t(8)=0.18, p>.05$ indicating that 
the GO group $(M=20.60, S D=6.92)$ had almost the same English reading skills as the summary group $(M=21.40, S D=5.64)$.

\section{Material}

Text. An English reading passage ( 245 words, Flesch Reading Ease = 72.5, Flesch-Kincaid Grade Level = 6.3) was used (see Appendix). This text was taken from a textbook designed to teach paragraph reading (Fukuzaki \& Yoneyama, 1999). This particular passage concerned a psychological experiment in which researchers predicted the future character of children according to their behavior in early childhood. The rhetorical structure of this text appears in Table 1 . This passage was printed on one B4 $(250 \times 353 \mathrm{~mm})$ page.

Adjunct display. Students in the GO group were asked to construct GOs as an adjunct display to the text, while those in the summary group were required to produce summaries for the same purpose. The construction of both GOs and summaries is intended to assist with the individual comprehension of textual content. Students in both groups were instructed to produce their adjunct displays on one A4 $(210 \times 297 \mathrm{~mm})$ page. It was emphasized that they were expected to make the most of these individually created adjunct aids for better understanding of the text.

\section{Procedure}

Several sessions were conducted during spring vacation using a typical senior high school classroom with one to three participants each time. Invited into the room individually, they were told that the purpose of the study was to establish the way in which they read a text and construct an accompanying adjunct display-not to test them personally. The data collection methods used in this study was think-aloud protocol analysis. Although this think-aloud protocol technique is still controversial in that (a) it is difficult to measure what participants do automatically and thus are not aware of (Okouchi, 2001), and (b) this technique itself can influence the students' natural cognitive processes (Kaiho \& Harada, 1993), I decided to employ it, since it has been used in a number of studies investigating reading strategies (e.g., Block, 1986; 1992; Hartman, 1995; Kletzien, 1991; Narvaez, van den Broek, \& Ruiz, 1999; Olshavsky, 1977; Philips, 1988; Stromso, Helge, \& Braten, 2002; Yoshida, 1997) as well as in some studies examining students' use of GOs (e.g., Guthrie, Weber, \& Kimmerly, 1993; Moore \& Scevak, 1997; Schnotz, Picard, \& Hron, 1993). 
Table 1. The Rhetorical Structure of the English Passage Used

\begin{tabular}{l} 
[the 1st paragraph] \\
\hline $\begin{array}{l}\text { This paragraph explained an experiment in which small children were } \\
\text { instructed not to eat a marshmallow, although they could get it. }\end{array}$ \\
\hline [the 2 nd paragraph] \\
\hline $\begin{array}{l}\text { This paragraph described the different behaviors of those children; } \\
\text { some could not resist the temptation of eating the marshmallow while } \\
\text { others could endure the temptation. }\end{array}$ \\
[the 3rd paragraph] \\
\hline $\begin{array}{l}\text { This paragraph reported the findings of the experiment. High school } \\
\text { students, who had shown patience in their early childhood outper- } \\
\text { formed those who had not, with respect to both their personalities and } \\
\text { their academic achievement. }\end{array}$
\end{tabular}

Participants first underwent a practice session (of approximately 30 minutes' duration) to familiarize themselves with the required thinkaloud procedure and the audio recording process. The practice session was conducted according to the procedure proposed by Ericsson and Simon (1984). It consisted of participants reading four short sample English passages and solving mathematical problems while simultaneously reporting what they were thinking. They were cautioned not to explain or analyze their thoughts while thinking aloud, and if they were silent for a particularly long period of time, they were prompted to report what they were thinking. Participants were asked to report in the same language in which they were thinking - either Japanese or English; all participants used only Japanese. The practice session continued until the author determined that the participants were able to perform the thinkaloud process with ease. In order to avoid bias or imitation, no particular model or example was given.

After the practice session participants were provided with the text, instructions, and a blank sheet of paper upon which to produce their GOs or summaries. They were allowed to read and study the material without time constraint (their average study time was about 44 minutes); they were also allowed to consult a dictionary at any time throughout the session. All verbal reports were audiotaped. Following this stage and a 10minute break, the participants completed the English reading skills test 
(50 minutes) and were finally dismissed after being asked to not discuss the content of the material with other participants. One day after the session, the participant(s) were reconvened in the classroom and were given a delayed-recall test where they were asked to write down everything they remembered about the text on one A4 sheet of paper. The entire session was conducted by the author alone and all instructions were issued in Japanese. Even when there were three participants (the maximum mentioned earlier) in the room where the session was conducted, the entire session-including the practice session--was conducted individually. The room was rather large, so even when one participant was being instructed or was doing the practice session, the others were unable to observe what was happening. Since this procedure was repeated several times with one to three students at a time, all were strictly instructed not to talk with other participants about the TOEFL English reading skills test, the English passage, or about what happened during the sessions.

\section{Think-Aloud Protocols And Scoring}

Think-aloud protocol analysis was used to explore the relative quantity of the types of reading strategies employed by participants. The verbal protocol data was categorized into either of the following two strategies: local linguistic strategies (such as questioning the meaning of a word), and general comprehension strategy (such as recognizing textual structure). In order to investigate which strategies were used more, the taxonomy of reading strategies developed by Block (1986) was employed. This taxonomy provides a useful classification system for general comprehension and local linguistic strategies and was developed using think-aloud protocols conducted with expository texts. Moreover, Block used beginner level ESL college students as participants in her study. Considering that the participants in this study were third-year senior high school students, this classification, developed using beginning level students, was deemed appropriate. Alternative reading strategy classifications, for example, those of Anderson (1991) or Sarig (1993), were not deemed appropriate to this study. Almost 40\% (18 out of 47) of Anderson's classifications were specific to test-taking strategies, and although Sarig did investigate the process of producing a summary, the classification system was developed by examining one proficient EFL student, and as such does not provide the beginner-level measure applicable to this study.

When participants reported anticipating the text, recognizing text structure, integrating information, questioning the text, interpreting the 
text, associating information in the text with other information outside the text, commenting on the text, monitoring their own reading, correcting their reading, or reacting to the text, then these reports were placed in the general comprehensive strategy category. If students reported paraphrasing English words, rereading the English text, questioning the meaning of an English clause or sentence, questioning the meaning of English words, or solving vocabulary problems with English words, then the reports were placed in the local linguistic strategy category. The frequency of each type of strategy was counted and the results of the GO group and the summary group were compared.

All of the participants' recorded verbalizations during the think-aloud protocols were transcribed by the author. The transcripts of the verbal protocols were then matched with the corresponding sentences in the text. Each protocol was analyzed by the author and another coder to identify which type of strategy the participants used more, local linguistic or general comprehension. Intercoder reliability was $91 \%$.

When scoring the delayed-recall test, each sentence of the source text was considered to contain one specific and independent fact which could be potentially referred to by participants in their tests. For instance, the sentence "Some children grab for the treat as soon as they are out the door," has two specific and independent facts ("grab for the treat" and "out the door."). Thus, theoretically, if a participant in the recall test wrote only "children took the treat," only one point would be given. However, if they wrote "children took the treat after going out," two points would be given. The source text contained 16 sentences in all, and a score of one point was assigned to each. The author examined the completed tests and divided the information in each into separate passages which referred to the relevant sentence of the source text. Then, the author and another researcher analyzed independently whether there was agreement between the students' passage and the corresponding source text sentence with one point being awarded for each correct reference (16 points being the maximum possible score). Intercoder reliability turned out to be $96.88 \%$. Any discrepancies remaining in coding were resolved through discussion.

\section{Results}

All statistical tests were conducted at the level of $\alpha=.05$. 


\section{Adjunct Display Tasks}

As mentioned earlier five students failed to successfully complete their GO or summary tasks. Three students failed to complete their GOs; they tried to construct GOs, but instead wrote sentential memorandums rather than organized spatial displays. Similarly, 2 students failed to successfully complete their summaries; they simply translated the entire text into Japanese. The data of those who failed to complete the task was excluded and not analyzed. Figure 1 shows examples of successful and unsuccessful GOs. Figure 2 shows an example of a successful summary. Interestingly, all successful GOs appear to be very similar in format; children who ate the marshmallow were represented on the top right of the page, children who didn't were represented on the top left. Accordingly, the future characters of the children were recorded at the bottom of the page in corresponding positions and linked by arrows. All the successfully completed GOs reveal an advantage of two-dimensional spatial display: the GO allows immediate comparison between the behavior of the children in childhood and their future characteristics (discovered by vertical flow), as well as immediate comparison between the two different characteristics (discovered by using horizontal comparison).

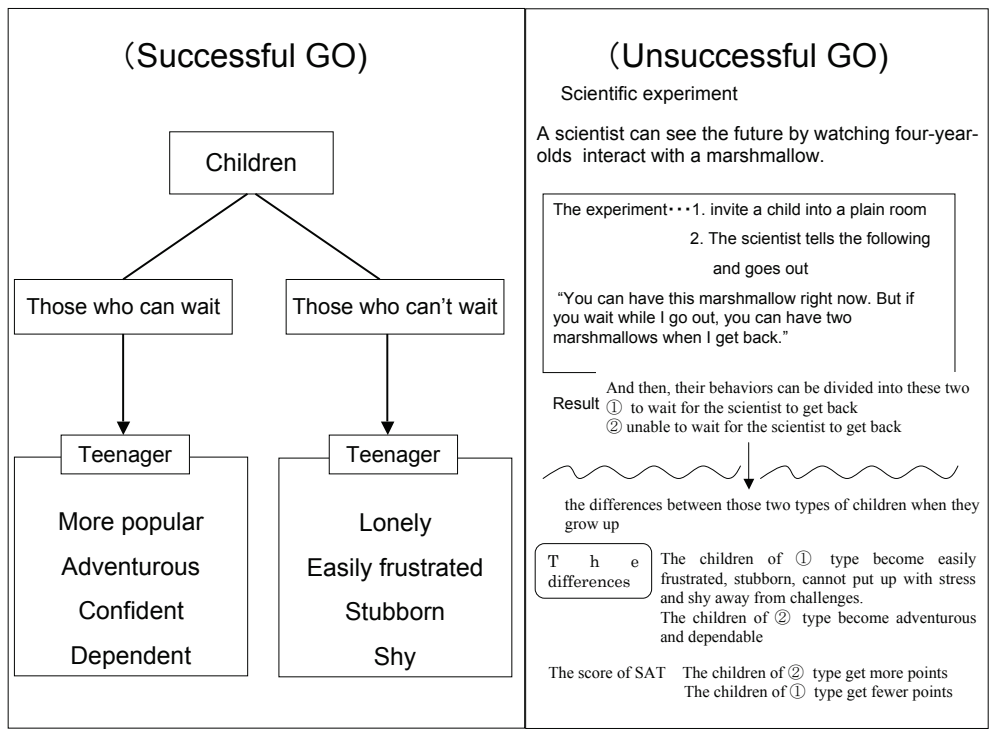

Figure 1. Examples of successful and unsuccessful GOs. (Translated here from the original Japanese by the author) 
科学者はマシュマロを使った実験で、4歳児を見て将来がわかる。マシュマ 口を食べるのを我慢できる子とできない子がいる。忍耐力のある子は順応力 があり、人気者で冒険好きな自信のある子になる。誘惑に負けた子供は孤独 で頑固な子になる。

Scientists can predict the future by watching four-year-olds interact with a marshmallow. Those who can resist the temptation to eat the marshmallow grow up to be well-adjusted, popular, adventurous, and confident, while those who cannot grow up to be lonely and stubborn.

Figure 2. Example of a successful summary. (Translated here from the original Japanese by the author.)

\section{Reading Strategies}

Table 2 provides the mean as a percentage and the standard deviation of each level of reading strategy reported during the think-aloud procedure. Percentages were used rather than raw data since raw usage amounts can differ greatly depending on whether or a participant is talkative or not. Overall, the GO group used general comprehension strategies 51.65\% of the time and local linguistic strategies $48.48 \%$ of the time, while the summary group used general comprehension strategies $23.25 \%$ of the time and local linguistic strategies $77.56 \%$ of the time. Examples of the protocols classified as general comprehension or local linguistic strategy for both groups are shown in Table 3.

Table 2. Means as a Percentage and Standard Deviations of Reading Strategies for Each Group

\begin{tabular}{lcc}
\hline & \multicolumn{2}{c}{ Display type } \\
\cline { 2 - 3 } & GO & Summary \\
\hline General comprehension & \\
$M(\%)$ & 51.64 & 23.24 \\
$S D$ & 18.28 & 11.59 \\
Local linguistic & & \\
$M(\%)$ & 48.48 & 77.56 \\
$S D$ & 18.44 & 11.20 \\
\hline
\end{tabular}


Table 3. Examples of General Comprehension and Local Linguistic Strategies According to Block's (1986) Taxonomy (Sentences in brackets were translated by the author)

\section{General comprehension strategies}

The text: A survey of the children's parents and teachers found that those who as four-year-olds had the patience to wait for the second marshmallow generally grew up to be better adjusted, more popular, adventurous, confident and dependable teenagers.

Protocol: “へえ・・・冒険好きなの?でも待てるんでしょ？・・あたし・待 てないほうが冒険好きな気がするよ・・・”

[ Hmm... He likes adventure? But he can wait, right? I think the ones who can't wait are more adventurous.]

\section{Local linguistic strategies}

The text: the same sentence as above

Protocol: “adjust ・適応? ・ ・ adjustって言う言葉・・ん一かっこいい・・ ・・adjust・これ遅いなあ・・適用・・・・順応・洗脳する・・・順応・適 用・順応しやすい・・順応性か”

[ Adjust, adapt? What's this word, "adjust"? Let's see, it sounds cool; adjust; I'm being slow; apply? Accustom, brainwashing? Accustom, adapt, accustom-this means accustom.]

A $2 \times 2$ (Adjunct Displays $\times$ Reading Strategies) factorial analysis of variance (ANOVA) was conducted in order to determine the statistical significance of the difference between the general comprehension and local linguistic strategies used by the two groups. Statistical analysis revealed that the effect of strategy (general comprehension strategy vs. local linguistic strategy) was not significant $[F(1,8)=1.68, p>.05]$. However, there was a significant main effect of group (GO vs. Summary), $[F(1,8)=$ $5.61, p>.05]$ with the GO group employing more general comprehension strategies and fewer local linguistic strategies than the summary group (see Table 2). In addition, the Strategy x Group interaction was significant $[F(1,8)=7.08, p>.05]$. A post hoc Ryan's procedure indicated that display type had a significant effect on the strategy. Using a sentential adjunct display (summary) caused students to employ more local linguistic strategies than general comprehension strategies, whereas using a spatial adjunct display (GO) caused equal strategy use. 


\section{Task Completion Time}

Table 4 shows the means and standard deviations of participants' task completion time. The average time was 44.40 minutes. According to the $t$ test, the average task completion times of the two groups did not differ significantly, $t(8)=0.36, p>.05$.

\section{One-Day Delayed Free Recall Test}

Table 4 also shows the means and standard deviations of the delayed free recall. The GO group's average score was 6.73 out of 16, and the summary group's was 5.97 out of 16 . According to the $t$-test, the average scores of the two groups did not differ significantly, $t(8)=0.44, p>.05$.

Table 4. Means and Standard Deviations for Task Completion Time and Delayed Free-recall Tests for Each Group

\begin{tabular}{lcc}
\hline & \multicolumn{2}{c}{ Display type } \\
\cline { 2 - 3 } Test & GO & Summary \\
\hline Task Completion Time & & \\
$M$ (minutes) & 45.80 & 43.00 \\
$S D$ & 13.07 & 8.41 \\
Delayed free-recall tests & & \\
$M$ (out of 16) & 6.73 & 5.97 \\
$S D$ & 2.24 & 2.63 \\
\hline
\end{tabular}

\section{Discussion}

The research question addressed in this study is: do different adjunct display types (GO vs. summary) cause students to use different proportions of strategy use (general comprehension strategy vs. local linguistic strategy)?

Regarding strategy variation between the two groups, the results of the ANOVA indicated that students in the GO group used significantly fewer local linguistic strategies than those in the summary group, and that the GO group employed significantly more general comprehension strategies than the summary group.

It was confirmed that English reading skills did not differ between the groups and that students in both groups demonstrated an equally 
successful comprehension of the text material and spent an almost equal amount of time on the task. The only difference in the treatment of the two groups was the type of adjunct display used as an aid to study. It can be concluded that the different qualities of the display types (spatial vs. sentential) are responsible for the variations evident in the proportion of strategy use (general vs. local linguistic comprehension).

The summaries and GOs produced bear out the difference in computational efficacy (Larkin \& Simon, 1987). The following example summary was produced by a student:

Scientists can predict the future by watching 4-year-olds interact with a marshmallow. Those who can resist catching it grow up to be well-adjusted, popular, adventurous, and confident, while those who can't grow up to be lonely and stubborn.

In order for the student creating this particular prose summary to contrast the contrasting characteristics of children, she had to a) search through this summary to discover that children who didn't eat the marshmallow grew up to become good, b) retain this information in her working memory, c) search for the relevant information, and d) comprehend and compare the significance of the contrasting behavior and its subsequent outcomes. On the other hand, for a student using a GO to obtain the same contrasting information, she just has to a) scan vertically the data on children who didn't eat the marshmallow, b) do likewise with the data on children who did eat it, and c) compare the data horizontally (see Figure 3).

The completed GOs produced by the GO group all contain this advantage of computational efficacy. It can be argued that in order to produce GOs equipped with this computational efficacy, they had to expend greater cognitive resources on general comprehension reading strategy, such as recognizing text structure or integrating information, than on local linguistic reading strategy such as paraphrasing English words or solving grammatical problems. As a result, the proportion of general comprehension reading strategy use of students in the GO group was significantly higher than that of those in the summary group.

With respect to the depth of text understanding, Kintsch (1994) distinguished learning text from learning from text. Learning text indicates being able to reproduce it in some form. For instance, when students are required to recite a poem or a passage of literature, this activity can be seen as learning text. Learning from text means using the information gained 


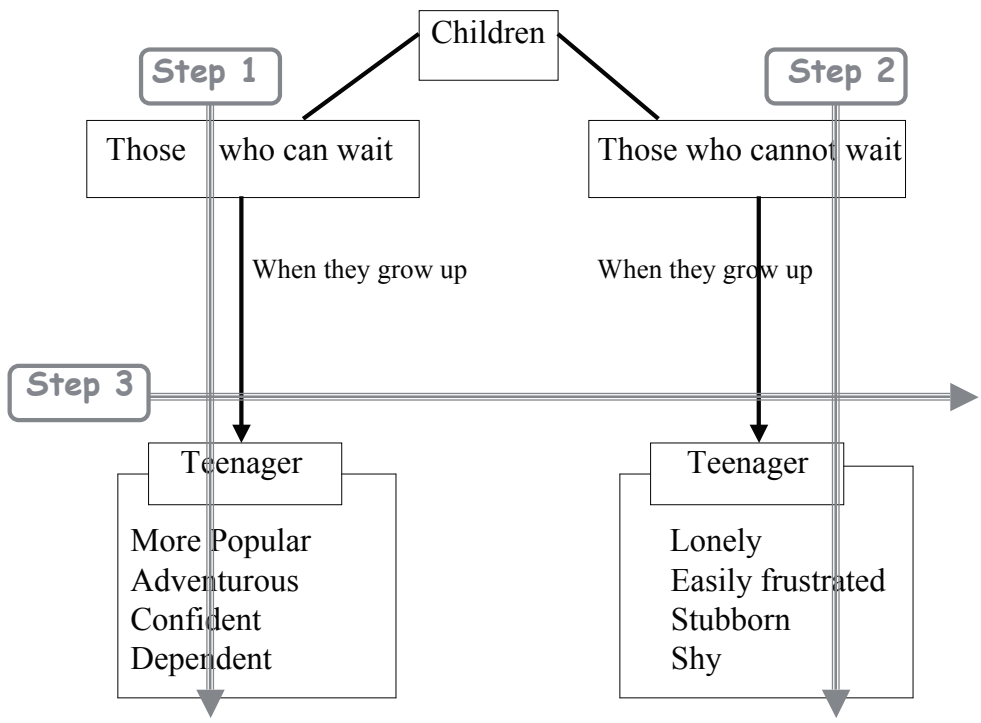

Figure 3. Process Undertaken by Students Studying with a GO When Locating Contrasts.

from the text in other ways, not just for reproduction. For example, when reading a scientific explanatory text, students can connect text information with their prior knowledge and thus infer new ideas. For this reason, learning from text is viewed as a deeper understanding of text (Kintsch, 1988; van Dijk \& Kintsch, 1983). Cognitive activities such as integration or inference are particular features of learning from text (Kintsch, 1994).

The findings presented in this study are of significance in that constructing GOs has the potential to urge EFL readers to use greater resources for general comprehension reading strategy, which can lead to students' learning from text rather than learning text (Kintsch, 1994). Students in the GO group used more general comprehension strategies such as inference or information integration, which are both important cognitive activities in order for EFL readers to implement learning from text.

In this study, the number of participants (10) was rather small, so it is not possible to generalize that the different proportion of strategies employed by the two groups (GOs vs. summaries) can lead to either learning text or learning from text (Kintsch, 1994) solely from the findings presented. In addition, the task to determine how well students comprehended the text was a delayed free recall test, and thus only adequate to examine 
the students' comprehension at the level of a propositional textbase for learning text, and not of a situation model for learning from text (Kintsch, 1988; van Dijk \& Kintsch, 1983), so it is reasonable that there were not any significant differences regarding the delayed free-recall tests.

As this study is an exploratory study, further research is necessary with a larger number of participants, as well as a variety of text types, to consider and examine the application of students' constructing GOs as aids to EFL reading. In order to promote learning from text (Kintsch, 1994), future research is needed that examines how students comprehend a text, that requires readers to connect what is explicitly stated in the text with their background knowledge, and that requires them to derive inferences from this linkage.

Akio Suzuki is a full-time lecturer at Josai University, Saitama. His research interests include TEFL, cognitive psychology, and educational psychology.

\section{References}

Alderson, J.C. (2000). Assessing reading. New York: Cambridge University Press. Alesandrini, K. L. (1981). Pictorial-verbal and analytic holistic learning strategies in science learning. Journal of Educational Psychology, 73, 358-368.

Alvermann, D. E., \& Boothby, P. R. (1986). Children's transfer of graphic organizer instruction. Reading Psychology: An International Quarterly, 7, 87-100.

Anderson, N. J. (1991). Individual differences in strategy use in second language reading and testing. Modern Language Journal, 75, 460-472.

Barnett, M. A. (1988). Reading through context: How real and perceived strategy use affects L2 comprehension. Modern Language Journal, 72, 150-162.

Barron, R. F. (1980). A systematic research procedure, organizers, and overviews: A historical perspective. Paper presented at the annual meeting of the National Reading Conference, San Diego, CA.

Bean, T. W., Singer, H., Sorter, J., \& Frazee, C. (1986). The effect of metacognitive instruction in outlining and graphic organizer construction on students' comprehension in a tenth-grade world history class. Journal of Reading Behavior, 18, 153-169.

Block, E. (1986). The comprehension strategies of second language readers. TESOL Quarterly, 20, 463-494.

Block, E. (1992). See how they read: Comprehension monitoring of L1 and L2 readers. TESOL Quarterly, 26, 319-343.

Dean, R. S., \& Kulhavy, R. W. (1981). Influence of spatial organization on prose learning. Journal of Educational Psychology, 73, 57-64. 
Educational Testing Service. (1998). TOEFL Sample Test (6 ${ }^{\text {th }}$ edition). Princeton, NJ: Author.

Ericsson, K. A., \& Simon, H. A. (1984). Protocol analysis: Verbal reports as data. Cambridge, MA: The MIT Press.

Fukuzaki, G., \& Yoneyama, T. (1999). Strategies for paragraph reading. Tokyo: Kawai Press.

Geva, E. (1983). Facilitating reading comprehension through flowcharting. Reading Research Quarterly, 18, 384-405.

Grabe, W. (1999). Developments in reading research and their implications for computer-adaptive reading assessment. In M. Chalhoub-deVille (Ed.), Issues in computer-adaptive testing of reading proficiency (pp. 11-47). Cambridge: Cambridge University Press.

Grabe, W., \& Stoller, F. L. (2002). Teaching and researching reading. London: Longman.

Guthrie, J. T., Weber, S., \& Kimmerly, N. (1993). Searching documents: Cognitive processes and deficits in understanding graphs, tables, and illustrations. Contemporary Educational Psychology, 18, 186-221.

Hartman, D. K. (1995). Eight readers reading: The intertextual links of proficient readers multiple passages. Reading Research Quarterly, 30, 520-561.

Hashimoto, H., Ibe, T., Furukawa, M., \& Takanashi, Y. (2002). Sunshine reading. Tokyo: Kairyudo.

Hatch, E. (1979). Reading a second language. In M. Celce-Murcia \& L. McIntosh (Eds.), Teaching English as a second or foreign language. Rowley, MA: Newbury House Publishers.

Hawk, P. P. (1986). Using graphic organizers to increase achievement in middle school life science. Science Education, 70, 81-87.

Hershberger, W. A., \& Terry, D. F. (1965). Typographical cuing in conventional and programmed texts. Journal of Applied Psychology, 49, 55-60.

Holley, C. D., \& Dansereau, D. F. (1984). Spatial learning strategies. Orlando, FL: Academic Press.

Irwin, J. D. (1986). Teaching reading comprehension process. Englewood Cliffs, NJ: Prentice-Hall.

Kaiho, H., \& Harada, E. (1993). Purotokoru bunseki nyu-mon [Introduction to protocol analysis]. Tokyo: Shinyo-sha.

Kintsch, W. (1988). The role of knowledge in discourse comprehension: A construction-integration model. Psychological Review, 95, 163-182.

Kintsch, W. (1994). Text comprehension, memory, and learning. American Psychologist, 49, 294-303.

Kletzien, S. B. (1991). Strategy use by good and poor comprehenders reading expository text of different levels. Reading Research Quarterly 26, 67-86.

Koda, K. (1999). Development of L2 intraword orthographic sensitivity and decoding skills. Modern Language Journal, 83, 51-64. 
Langer, J. (1982). The reading process. In A. Berger \& H. A. Robinson (Eds.), Secondary school reading: What research reveals for classroom practice (pp. 39-52). Urbana, IL: ERIC Clearinghouse on Reading and Communication Skills.

Larkin, J. H., \& Simon, H. A. (1987). Why a diagram is (sometimes) worth ten thousand words. Cognitive Science, 11, 65-100.

Levie, W. H., \& Lentz, R. (1982). Effects of text illustrations: A review of research. Educational Communication and Technology Journal, 30, 195-232.

Mayer, R. E. (1997). Multimedia learning: Are we asking the right questions? Educational Psychologist, 32, 1-19.

Moore, P. J., Chan, L. K. S., \& Au, W. K. (1993). High school students' use of diagrams during reading. Journal of Research in Reading, 16, 57-71.

Moore, P. J., \& Scevak, J. J. (1997). Learning from texts and visual aids: A developmental perspective. Journal of Research in Reading, 20, 205-223.

Narvaez, D., van den Broek, P., \& Ruiz, A. B. (1999). The influence of reading purpose on inference generation and comprehension in reading. Journal of Educational Psychology, 91, 488-496.

Novak, J. D. (1991). Clarifying with concept maps. The Science Teacher, 58, 45-49

Ohura, A., Tennuma, E., Ando, T., Toda, Y., \& Yanagisawa, T. (2002). New cosmos reading. Tokyo: Sanshyusha.

Okouchi, S. (2001). Strategies and meta-cognition in discourse comprehension. In O. Akimichi, K. Akita, \& M. Kuno (Eds.), The psychology of discourse comprehension (pp. 66-79). Tokyo: Kitaojishobou.

Olshavsky, J. E. (1977). Reading as problem solving: An investigation of strategies. Reading Research Quarterly, 12, 654-674.

Omaggio, A. C. (1979). Pictures and second language comprehension: Do they help? Foreign Language Annals, 12, 107-116.

Philips, L.M. (1988). Young readers' inference strategies in reading comprehension. Cognition and Instruction, 5, 193-222.

Rinehart, S. D., Stahl, S. A., \& Erickson, G. L. (1986). Some effects of summarization training on reading and studying. Reading Research Quarterly, 21, 422-438.

Robinson, D. H. (1998). Graphic organizers as aids to text learning. Reading Research and Instruction, 37, 85-105.

Robinson, D. H., \& Kiewra, K. A. (1995). Visual argument: Graphic organizers are superior to outlines in improving learning from text. Journal of Educational Psychology, 87, 455-467.

Robinson, D. H., Robinson, S. L., \& Katayama, A. D. (1999). When words are represented in memory like pictures: Evidence for spatial encoding of study materials. Contemporary Educational Psychology, 24, 38-54.

Sarig, G. (1993). Composing a study-summary: A reading / writing encounter. In J. Carson \& Leki, I. (Eds.), Reading in the composition classroom: Second language perspectives (pp. 161-182). Boston: Heinle \& Heinle. 
Schnotz, W., Picard, E., \& Hron, A. (1993). How do successful and unsuccessful learners use texts and graphics? Learning and Instructions, 3, 181-199.

Silberstein, S. (1994). Technique and resources in teaching reading. Oxford: Oxford University Press.

Sims, V. K., \& Hegarty, M. (1997). Mental animation in the visuospatial sketchpad: Evidence from dual-task studies. Memory and Cognition, 25, 321-332.

Snowman, J., \& Cunningham, D. J. (1975). A comparison of pictorial and written adjunct aids in learning from text. Journal of Educational Psychology, 15, 66-82.

Stromso, H. I., \& Braten, I. (2002). Norwegian law students' use of multiple sources while reading expository texts. Reading Research Quarterly, 37, 208-227.

Urquhart, S., \& Weir, C. (1998). Reading in a second language: Process, product, and practice. New York: Longman.

van Dijk, T. A., \& Kintsch, W. (1983). Strategies of discourse comprehension. New York: Academic Press.

Waller, R., \& Whalley, P. (1987). Graphically organized prose. In E. de Corte (Ed.), Learning and instruction: European research in an international context (pp. 369381). Leuven, Belgium: Leuven University Press.

Winn, B. (1987). Charts, graphs, and diagrams in educational materials. In D. M. Willows \& H. A. Houghton (Eds.), The psychology of illustration: Basic research Volume 1 (pp. 152-198). New York: Spronger-Verlag.

Winn, W. (1990). Encoding strategies and other influences on the retrieval of information from maps and diagrams. Paper presented at the annual meeting of the American Educational Research Association, Boston, MA.

Winn, W., Li, T., \& Schill, D. (1991). Diagrams as aids to problem solving: Their role in facilitating search and computation. Educational Technology Research and Development, 39, 17-29.

Winograd, P. N., \& Bridge, C. A. (1986). The comprehension of important information in written prose. In J. F. Baumann (Ed.), Teaching main idea comprehension (pp. 18-48). Newark, DE: International Reading Association.

Yoshida, S. (1997). Strategies in answering cloze items: An analysis of learner's think-aloud protocols. JACET Bulletin, 28, 207-222. 


\section{Appendix}

(English passage used as material)

It turns out that a scientist can see the future by watching four-yearolds interact with a marshmallow. The researcher invites children, one by one, into a plain room and begins the gentle torment. You can have this marshmallow right now, he says. But if you wait while I run an errand, you can have two marshmallows when I get back. And then he leaves.

Some children grab for the treat, as soon as he's out the door. Some last a few minutes before they give in. But others are determined to wait. They cover their eyes; they put their heads down; they sing to themselves; they try to play games. When the researcher returns, he gives these children their two marshmallows. And then science waits for them to grow up.

By the time the children reach high school, something remarkable has happened. A survey of the children's parents and teachers found that those who as four-year-olds had the patience to wait for the second marshmallow generally grew up to be better adjusted, more popular, adventurous, confident and dependable teenagers. The children who gave in to temptation early on were more likely to be lonely, easily frustrated and stubborn. They couldn't put up with stress and shied away from challenges. And when some of the students in the two groups took the Scholastic Aptitude Test, which U.S. students take when applying to university, the kids who had waited longer scored an average of 210 points higher. 